\title{
PENGARUH MEDIA PEMBELAJARAN ONLINE DALAM PEMAHAMAN DAN MINAT BELAJAR SISWA PADA KONSEP PELAJARAN FISIKA
}

\author{
Sundus Nurmaulidina1), Yoga Budi Bhakti1) \\ 1)Departemen Pendidikan Fisika, Fakultas IImu Pengetahuan Alam, Universitas Indraprasta PGRI, Jakarta Selatan, Indonesia \\ Corresponding author : Sundus Nurmaulidina \\ E-mail : Sundusmaulidina29@gmail.com
}

Diterima 01 Agustus 2020, Direvisi 03 Oktober 2020, Disetujui 03 Oktober 2020

\begin{abstract}
ABSTRAK
Penulisan makalah ini bertujuan untuk mengetahui pengaruh media pembelajaran online dalam pemahaman dan minat siswa dalam mempelajari konsep-konsep fisika dan untuk respon siswa mengenai penerapan media pembelajaran online, pemerintah memberlakukan kebijakan jarak sosial atau dikenal sebagai jarak fisik dan oleh karena itu sekolah memutuskan untuk belajar jarak jauh yang ditakuti selama pandemi menggunakan media pembelajaran online minat belajar siswa akan menurun.Dari hasil survai menggunakan kuesioner di google form terhadap siswa Sekolah Menengah Atas diperoleh $18,8 \%$ setuju menggunakan media pembelajaran online dan $52,75 \%$ tidak setuju menggnakan media pembelajran online. dari hasil data tersebut dikatakan "tidak kuat" ini menunjukkan respon siswa segatif terhadap menggunakan media pembelajran online. minat belajar siswa lebih meningkat bila pembelajaran online dilakukan di dalam kelas. selama pandemi berlangsung sebaiknya pendidik atau guru lebih keatif dalam melakukan pemebelajaran online dirumah agar siswa tidak merasa bosan dan semangat saat sedang pembelajaran jarak jauh. sehingga minat belajar siswa dapat meningkat dan memahami konsep fisik
\end{abstract}

Kata kunci: covid 19; pembelajaran; fisika.

\begin{abstract}
Writing this paper aims to determine the effect of online learning media in students' understanding and interest in learning the concepts of physics and for student responses regarding the application of online learning media, the government imposed social distancing policy or known as physical distancing and therefore schools decided to distance learning feared during the pandemic using online learning media student learning interest will decrease. From the survey results using a questionnaire on the Google form of high school students obtained $18.8 \%$ agreed to use online learning media and $52.75 \%$ did not agree to use online learning media. from the results of the data it is said "not strong" this shows the response of students to use the online learning media. Student interest in learning increases when online learning is done in the classroom. During the pandemic, educators or teachers should be more active in conducting online learning at home so that students do not feel bored and excited while studying distance learning. so that students' interest in learning can increase and understand physical concepts
\end{abstract}

Keywords: covid 19; learning; physics

\section{PENDAHULUAN}

Realistis dunia pada saat ini dihadapkan dengan permasalahan yang cukup kompleks. Pandemi Covid-19 memaksa kebijakan social distancing, atau di Indonesia lebih dikenalkan sebagai physical distancing (menjaga jarak fisik) untuk meminimalisir persebaran Covid-19. Jadi, kebijakan ini diupayakan untuk memperlambat laju persebaran virus Corona di tengah masyarakat. Kementrian Pendidikan dan Kebudayaan (Kemdikbud) merespon dengan kebijakan belajar dari rumah, melalui pembelajaran daring dan disusul peniadaan Ujian Nasional untuk tahun ini.
Tantangan Pembelajaran Persebaran virus Corona yang massif di berbagai negara, memaksa kita untuk melihat kenyataan bahwa dunia sedang berubah. Kita bisa melihat bagaimana perubahan-perubahan di bidang teknologi, ekonomi, politik hingga pendidikan di tengah krisis akibat Covid-19. Perubahan itu mengharuskan kita untuk bersiap diri, merespon dengan sikap dan tindakan sekaligus selalu belajar hal-hal baru. Indonesia tidak sendiri dalam mencari solusi bagi peserta didik agar tetap belajar dan terpenuhi hak pendidikannya. Sampai 1 April 2020, UNESCO mencatat setidaknya 1,5 milyar anak usia sekolah yang terdamapk Covid 19 di188 negara 
termasuk 60 jutaan diantaranya ada di negara kita.

Semua negara terdampak telah berupaya membuat kebijakan terbaiknya dalam menjaga kelanggengan layanan pendidkan. Indonesia juga menghadapi beberapa tantangan nyata yang harus segera dicarikan solusinya: (1) ketimpangan teknologi antara sekolah di kota besar dan daerah, (2) keterbatasan kompetensi guru dalam pemanfaatan aplikasi pembelajaran, (3) keterbatasan sumberdaya untuk pemanfaatan teknologi Pendidikan seperti internet dan kuota, (4) relasi guru- murid-orang tua dalam pembelajaran daring yang belumintegral.

Pemberlakuan kebijakan physical distancing yang kemudian menjadi dasar pelaksanaan belajar dari rumah, dengan pemanfaatan teknologi informasi yang berlaku secara tiba- tiba, tidak jarang membuat pendidik dan siswa kaget termasuk orang tua bahkan semua orang yang berada dalam rumah. Pembelajaran teknologi informasi memang sudah diberlakukan dalam beberapa tahun terakhir dalam sistem pendidikan di Indonesia. Namun, pembelajaran daringyang berlangsung sebagai kejutan dari pandemi Covid-19, membuat kaget hampir di semua lini, dari kabupaten/kota, provinsi, pusat bahkan dunia internasional.

Selanjutnya untuk aspek sikap siswa terhadap Fisika di sekolah, dapat diketahui tidak hanya dari beberapa publikasi penelitian, tetapi dari opini siswa di sekolah bahwa mereka tidak suka atau bahkan takut pada beberapa pelajaran khususnya pelajaran Fisika. Di sisi lain semua pihak menyadari bahwa Fisika merupakan IImu Pengetahuan Alam yang banyak memerlukan pemahaman konsep yang harus dipelajari oleh setiap siswa. Fisika merupakan pelajaran yang memberikan pengetahuan tentang alam semesta untuk berlatih berpikir dan bernalar, melalui kemampuan penalaran seseorang yang terus dilatih sehingga semakin berkembang, maka orang tersebut akan bertambah daya pikir dan pengetahuannya. Atas dasar inilah Fisika mutlak wajib diajarkan pada setiap siswa. Beberapa faktor yang mempengaruhi keberhasilan peserta didik dalam belajar fisika, diantaranya faktor internal yang meliputi kemampuan awal, tingkat kecerdasan, motivasi belajar, kebiasaan belajar, kecemasan belajar, minat belajar, dan sebagainya (Achmad, R. I., Mujasam, M., Yusuf, I., \& Widyaningsih, 2017). Sedangkan faktor eksternal meliputi lingkungan keluarga, lingkungan sekolah, lingkungan masyarakat, keadaan sosial ekonomi, dan sebagainya. Dalam penelitian ini, penulis memfokuskan pada faktor internal yang ada pada peserta didik dengan hasil yang dicapai oleh peserta didik. Faktor internal tersebut yaitu kemampuan awal dan minat belajar (Sakti et al., 2012). Pandemi Covid-19 merupakan masalah yang serius dan perlu mendapatkan perhatian penuh dari semua pihak, baik pemerintah, sekolah, masyarakat/ orang tua maupun siswa itu sendiri. Rendahnya hasil belajar Fisika siswa disebabkan oleh banyak hal antara lain: kurikulum yang padat, materi pada buku pelajaran yang dirasakan terlalu sulit untuk di ikuti, media belajar yang kurang efektif, laboratorium yang tidak memadai, kurang tepatnya penggunaan media pembelajaran yang dipilih oleh guru, kurang optimal dan kurangnya keselarasan siswa itu sendiri, atau sifat konvesional, dimana siswa tidak banyak terlibat dalam proses pembelajaran dan keaktifan kelas sebagian besar didominasi oleh guru lalu ditambah dengan physical distancing (menjaga jarak fisik) yang mengharuskan peserta didik agar tetap belajar dan terpenuhi hak pendidikannya dengan belajar darirumah (Sembiring, 2013).

Minat belajar ditumbuhkan sejak awal pembelajaran dengan menjelaskan manfaat mempelajari topik-topik fisika baik untuk bekal pendidikan lebih tinggi mapun untuk bekal hidup. Dengan mengetahui manfaat mempelajari fisika, akan tumbuh motivasi dan minat belajar. Selanjutnya motivasi dan minat belajar akan mempengaruhi hasil belajar siswa.

Tujuan penelitian yang saya akan lakukan adalah :

(1) Untuk mengetahui Minat belajar dan pemahaman peserta didik terhadap pelajaran fisika dengan menggunakan penerapan media pembelajaran online.

(2) Untuk mengetahui respon siswa mengenai penerapan media pembelajaranonline.

\section{METODE PENELITIAN}

Dengan segala kendala yang ada termasuk para peserta didik sudah menggunakan penerapan belajar dari rumah maka, metode yang diambil adalah pengumpulan data menggunakan angket atau kuesioner(Questionnaires).Kuesioner mewakili satu bagian dalam proses survey merupakan bagian yang sangat penting. Tahapan pada penelitian ini pada dasarnya berusaha menerapkan metode pengumpulan data dengan cara survei menggunakan angket. Setelah itu angket akan disebarkan kepada responden dalam bentuk angket atau kuesioner. Hasil dari pengumpulan data nantinya akan dilihat seberapa pengaruhnya pembelajaran fisika menggunakan basis Online 


\section{HASIL DAN PEMBAHASAN}

Hasil dari data observasi menggunakan angket atau kuesioner pada siswa/l sekolah yang sedang menerapkan belajar Online berpengaruh pada pemahaman dan minat Belajar fisika. Adapun pada pertanyaan pertama

Apakah anda merasa senang saat guru memberi Tugas Online fisika? 55 tanggapan
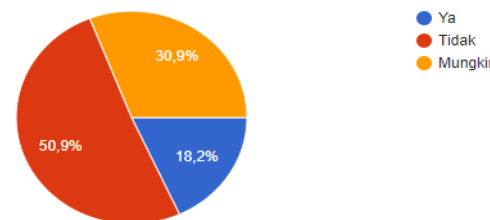

Gambar 1. Persentasee Diagram hasil pertanyaan Tugas Online

Hasil pengujian menggunakan angket atau kuesioner menunjukan data, bahwasannya lebih dominan siswa tidak menyukai pembelajaran yang diberikan secara online terbukti dari besar diagram yang terdapat pada gambar 1 .

Apakah anda paham dengan penjelasan guru ketika menjelaskan Materi Fisika secara online? 55 tanggapan

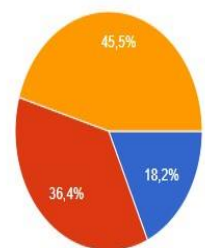

Ya Kadang-kadang

Gambar 2. Persentase Diagram hasil pertanyaan Materi Fisika

Dan dengan berbagai metode yang sudah diterapkan oleh guru agar siswanya dapat menerima pelajaran atau soal yang sudah diberikan, ternyata hasil yang didapat siswapun tidak sepenuhnya dapat memahami pelajaran yang sudah dijelaskan oleh gurunya, pembelajaran secara langsung di dalam kelaspun tidak bisa semua siswa dapat memahami pelajaran fisika ini dengan cepat.

Menurut Anda lebih baik belajar Fisika secara online atau secara Tatap muka langsung ? 55 tanggapan
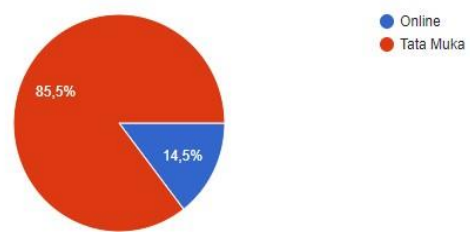

Gambar 3. Persentase Diagram hasil pertanyaan system pelajaraan

Dari sebagian besar kuesioner ini siswa pun memilih pembelajaran fisika lebih baik di lakukan dengan bertatap muka karena pada dasarnya pada pelajaran fisika itu butuh pemahaman yang ekstra untuk mengerjakan soal soal yang jawabannya lebih ke dalam rumus rumus dan itu tidak semua siswa dapat mencerna rumus rumus itu dengan cepat dan mudah.

Apa anda menyukai Pelajaran Fisika?

55 tanggapan

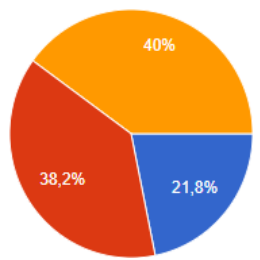

Tidak

- Mungkin

Gambar 4.Persentase Diagram hasil pertanyaan Pelajaran Fisika

Dari faktor faktor yang sudah ada pada saat pandemi ini bisa menyebabkan siswa yang tidak suka dengan fisika bisa tetap atau bahkan tetap tidak suka dengan pelajaran fisika, dan yang sudah fisika bisa menjadi acuan dia itu menantang dirinya agar bisa memahami pelajaran itu sendiri dengan kemampuan dia untuk belajar secara otodidak dan dengan siswa yang biasa saja akan tetap seprti itu bahkan bisa jadi mereka akan bersikap tidak peduli denga pelajaran fisika ini dan siswa pun akan mengerjakan atau mengikuti pelajaran online ini hanya sebatas formalitas.

\section{SIMPULAN DAN SARAN \\ Simpulan}

Berdasarkan hasil analisis data penelitian dan pembahasan, dapat ditarik kesimpulan sebagai berikut: 1) Terdapat pengaruh yang signifikan pada Pembelajaran Online terhadap minat belajarsiswa, 2) Terdapat pengaruh hasil belajar Fisika siswa yang berminat belajar tinggi dan berminat belajarrendah, dan 3) Pembelajaran secara langsung memang metode yang paling tepat dilakukan untuk pelajaranFisika

\section{Saran}

Berdasarkan kesimpulan dan implikasi penelitian maka beberapa saran terkait yang dapat penulis sampaikan pada penelitian ini adalah: 1) Media pembelajaran Fisika dapat diterapkan dalam berbagai metode pembelajaran, agar siswanya dapat memahami dengan mudah seperti perbanyak video animasi atau komik atau yang lainnya, 2) Diperlukan kerjasama antar guru Fisika dalam mengoptimalkan kemampuan siswanya dalam belajar Fisika. 


\section{DAFTAR RUJUKAN}

Achmad, R. I., Mujasam, M., Yusuf, I., \& Widyaningsih, S. W. (2017). HUBUNGAN ANTARA MOTIVASI BERPRESTASI DAN KEBIASAAN BELAJAR TERHADAP PRESTASI BELAJAR FISIKA. Prosiding Seminar Nasional.

Ardian Asyhari, R. H. (2015). Implementasi Pembelajaran Fisika SMA Berbasis Inkuiri Terbimbing Terintegrasi Pendidikan Karakter Untuk Meningkatkan Hasil Belajar Siswa Pada Materi Cahaya dan Optika. PPII, 37-49.

Astuti, S. P. (2015). Pengaruh Kemampuan Awal dan Minat Belajar terhadap Prestasi Belajar Fisika. Formatif: Jurnal IImiah Pendidikan MIPA. https://doi.org/10.30998/formatif.v5i1.167

Hariyanto, S. dan. (2012). Belajar dan pembelajaran: Teori dan konsep. Rosda.

Mulhayatiah, D., Suhendi, H. Y., \& Oktaviani, V. (2017). HUBUNGAN TINGKAT PENALARAN DENGAN HASIL BELAJAR MAHASISWA MELALUI EVALUASI TEKNIK RANKING TASK PADA MATA KULIAH LISTRIK MAGNET 1. WaPFi (Wahana Pendidikan Fisika). https://doi.org/10.17509/wapfi.v2i1.4865

Nugroho, E. (2018). Buku Prinsip prinsip Menyusun kuesioner. UB Press.

Sakti, I. (2013). Pengaruh Media Animasi Fisika dalam Model Pembelajaran Langsung (direct instruction ) terhadap Minat Belajar dan Pemahaman Konsep Fisika Siswa di SMA Negeri Kota Bengkulu. Prosiding Semirata FMIPA Universitas Lampung, 2013.

Sakti, I., Puspasari, Y. M., \& Risdianto, E. (2012). Pengaruh Model Pembelajaran Langsung (Direct Instruction) Melalui Media Animasi Berbasis Macromedia Flash Terhadap Minat Belajar Dan Pemahaman Konsep Fisika Siswa Di SMA Plus Negeri 7 Kota Bengkulu. Exacta.

Sembiring, S. W. B. (2013). Penerapan Model Pembelajaran Guided Discovery untuk Meningkatkan Hasil Belajar Siswa pada Materi Pokok Suhu dan Kalor di Kelas $X$ Semester II SMA Negeri 1 Kuala TA 2012/2013. UNIMED.

Supardi, S. U. S., Leonard, L., Suhendri, H., \& Rismurdiyati, R. (2015). Pengaruh Media Pembelajaran dan Minat Belajar Terhadap Hasil Belajar Fisika. Formatif: Jurnal IImiah Pendidikan MIPA. https://doi.org/10.30998/formatif.v2i1.86

Suparno, P. (2013). Metodologi Pembelajaran Fisika, Konstruktivistik dan Menyenangkan. Universitas Sanata
Dharma.

Young, H. D. \& R. A. F. (2003). Fisika Universitas. Erlangga. 